\title{
Eco, Peirce, and the Pragmatic Theory of Signs
}

\author{
Randall E. Auxier
}

\section{OpenEdition}

\section{Journals}

Electronic version

URL: http://journals.openedition.org/ejpap/1112

DOI: 10.4000/ejpap.1112

ISSN: 2036-4091

\section{Publisher}

Associazione Pragma

\section{Electronic reference}

Randall E. Auxier, «Eco, Peirce, and the Pragmatic Theory of Signs », European Journal of Pragmatism and American Philosophy [Online], X-1 | 2018, Online since 20 July 2018, connection on 01 May 2019. URL : http://journals.openedition.org/ejpap/1112 ; DOI : 10.4000/ejpap.1112

This text was automatically generated on 1 May 2019.

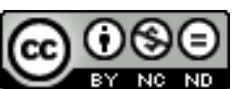

Author retains copyright and grants the European Journal of Pragmatism and American Philosophy right of first publication with the work simultaneously licensed under a Creative Commons AttributionNonCommercial-NoDerivatives 4.0 International License. 


\title{
Eco, Peirce, and the Pragmatic Theory of Signs
}

\author{
Randall E. Auxier
}

\section{Introduction}

1 The aim of the present essay is to examine the views of Charles S. Peirce and Umberto Eco with regard to signs and semiotics ${ }^{1}$ in order to assess their relation to Peirce's mature pragmatism (after 1903). Such an assessment might be done in a number of ways, but taking the path of semiotics, apart from being an obvious approach, also reveals some interesting things about pragmatism itself. Both thinkers attempted to set out a truly general theory of signs, and ran into difficulties on similar points. By "truly general," I mean a theory that covers all cases of meaning-generation, and while the theory may derive from generalizations that arise from particular experience, as human learning usually does, the truly general would not be dependent upon any given particular experience for its "validity" (although one hesitates to use that vexed word), or reference to the objective world. William James restricted the scope of pragmatism to what can be generalized from particular experience, but it is well known that Peirce would have none of that restriction, re-founding pragmatism to get around the nominalism implied by James's view.

2 The responses of Peirce and Eco to the difficulties that arose in seeking a truly general theory of signs were quite different. Both Peirce and Eco were allergic to transcendental claims (the latter more than the former) of the Kantian stripe, but apart from that shared aversion, they had different ideas about possibility. Peirce was not averse to sincere metaphysics. Eco was mostly indifferent to metaphysics and treated it as an interesting language game, peculiar to philosophers (and other cults and secret societies). In addition, Eco was not obsessed with avoiding nominalism, while for Peirce no greater error - one is tempted to say "sin" - could be committed.

3 These differences are far-reaching. And yet, the differences are not so deep as to prevent us from thinking of both Peirce and Eco as pragmatists, and perhaps of a similar stripe. 
Most of the differences between Eco and Peirce can be found also as differences between Peirce and almost all others we regularly call "pragmatists," especially James and Rorty. But Eco has some points of agreement with Peirce most others do not. None of the other standard pragmatists, apart from Charles Morris and Josiah Royce, could really be called a semiotician. Many doubt whether one ought to call either of these other two "pragmatists." This overlap provides more reason rather than less to undertake a comparison of Eco and Peirce on this precise question.

My strategy will be to examine the goal of achieving a "truly general" theory of signs (in a sense to be explained). The results may be applicable to the question of whether we ought to think of Morris and Royce as pragmatists in any robust way, and in considering the matter, one thing that will come to light is that we probably would not call Peirce a pragmatist at all had he not invented the term. ${ }^{2}$ The historians of pragmatism have tended to acknowledge Peirce for the term and then to make either James of Dewey the most important point of reference. Thus, we will need to clarify the sense of the term in considering Peirce and Eco in light of this history.

\section{Peirce and the Quest for a Truly General Theory of Signs}

5 In making his theory truly general, explaining every occurrence of meaning wherever meaning is possible, Peirce was obliged to claim that signs are more than abstract terms and operators. Beginning in 1903, he metaphysicalized signs and began to identify Firstness with possibility. For Peirce (for most of his career) the sign had both a concrete and an abstract nature. ${ }^{3}$ As he matured, the concrete-functional aspect of the sign gradually diminished in his thinking about signs, but whether it completely disappeared is, as we shall see, a point of contention among Peirce scholars. In any case, throughout the vast majority of his life, Peirce held that the sign is abstract in its capacity to be related to other signs without any required reference to their genesis, while signs are concrete in their capacity to be related to empirical functioning. ${ }^{4}$ The former is semiotic determination of signs by other signs, while the latter is determination of the world by signs and of signs by the world. In the former case, "logic" (in the broadest, normative sense) is the operating system and the relations revealed are reflective in character. In the latter, the determination is epistemic and has to do with the way beliefs are formed and acted upon.

6 Hence, there are two modes of determination of the sign, one abstract and logical (what I call "operative"), and the other concrete and functional. The relation between concrete and abstract determination, prior to 1903, was an on-going problem for Peirce..$^{5}$ I think 1903 marks a turning point due to Royce's very specific influence on Peirce which, in this instance, was largely negative, teaching Peirce what he did not want to assert. Peirce and Royce had been in correspondence about logic between 1898 and 1903, and 1899 is when Royce's The World and the Individual: Series One was published (from his Gifford lectures). ${ }^{6}$ Peirce's review of that book (which appeared in 1900) makes very plain that he saw what others did not in Royce's central claim: that the entire exercise was about the difference between which possibilities are "forced" upon our imaginations and which are not, when we make a knowledge claim. ${ }^{7}$ The full issue of possibility lies well beyond my current project, but it is crucial to note that over the next three years, Peirce adjusted his 
categories (yet again), and hence his "pragmatism" when he identified Firstness with possibility in 1903 (see below). ${ }^{8}$ No one else thought Royce's project was about which possibilities are forced on our imaginations in knowledge claims (I read every review; Peirce's is way off in a corner by itself). The claim that this is what Royce's book was about will seem extravagant and adventitious to most readers of the book. Peirce was always an active reader, in the sense that he often saw what others did not, and sometimes it is doubtful whether what he saw was really in the text.

7 From 1900 to 1903, Peirce misunderstood Royce's central claim. He believed that Royce critique of "realism" was an explicit critique of the sort of "realism" Peirce had been defending in correspondence with Royce and earlier. He was mistaken. Peirce's was not the sort of view Royce had in mind, as Peirce later learned, but the mistake led to one of the most creative and interesting misreadings in the history of philosophy - something Eco would appreciate, playfully and profoundly. In his review of Royce's book, Peirce therefore made up a criticism of himself that Royce never imagined, and began responding to that criticism (in the review and beyond), using Royce as a surrogate for the defender of the view.

8 The review was accompanied by correspondence with Royce (unfortunately only fragments survive - another point Eco would appreciate), which, if we can piece together with the published writings, creates an amazing, if unfinished, sketch of the movement from Peirce's struggles with his categories and semiotics within the syllogism to his rejection of the syllogism and the creation of a truly general theory of signs (after 1903).

In short, Royce and Peirce corresponded until it dawned on Peirce that his own version of "realism" was not Royce's target, but in the three years during which he had mistaken Royce's intent, he had devised arguments he thought were Royce's, but which were far better than Royce's, and which obliged him to throw off classical logic and develop a truly general theory of signs. It is a great moment in the play of signs. The great critic of Peirce, unbeknownst to Peirce, was Peirce. It is like Eco's Simone Simonini trying to catch a glimpse of the stranger in his house in The Prague Cemetery.

Peirce made numerous attempts to settle, in his own thinking, how these modes of determination (semiotic-abstract and epistemic-concrete) are related. The solution had to account for the efficacy of false beliefs and the metaphysical grounding of our capacity to form true beliefs in a self-correcting manner. What, in the end, is the relation between knowledge and meaning? Can one know what one cannot even make sense of? This question is peculiar to the pragmatic theory of knowledge, basically because pragmatists truly make knowing functional (in some sense), although clearly Peirce is not thinking about concrete "functioning" in the way James or Dewey did. For Peirce, fixing belief can be done in at least four ways, so tenacity and authority and a priorism are functional, but they are not self-correcting. ${ }^{9}$ Eco has obviously had a great deal of fun over the years creating narratives in which people never discover their errors. I will return to this point in the next section. For now, we see that Peirce has an unusual view. For most epistemologists, there is a tight relationship between meaning and knowledge. One cannot know what is meaningless, so the sets the "floor" of knowing. The ceiling is that one cannot know the full meaning of knowledge claim, because knowing a thing's full meaning requires knowing all it implies for the future, and we are not ideally situated inquirers. For the latter, there would be a convergence of knowledge and meaning. For us, there is a floor and a ceiling to the act of knowing, but having meaning is not sufficient for scientific knowing. There must be doubt and resolution, which makes the 
meaning explicit and places it in a context of future self-correction. So meaning can be ubiquitous but it must be harnessed or gathered in order to become known, for Peirce. We can imagine it as a round-up and branding of the herd. Some of the beasts may remain on the range, unlocated by the cowboys, meaningfully chewing the cud, suitable for the market, but they won't be part of the knowledge-herd..$^{10}$ They are merely operationally suitable for hamburger or steak, but those in the herd are functionally hamburger already. Thus, knowledge, for a pragmatist depends on being herded. From 1867 onward, Peirce characterized this gathering of meaning as the rise from "substance" to "being," from what might be predicated to what is predicated. ${ }^{11}$

11 After 1903 (perhaps due to the influence of Royce), Peirce shifted his interpretation of his categories and solved this problem by treating signs as determined only abstractly. $\mathrm{He}$ was unable to handle the question of concrete-functional determinations of meaning within the theory of signs after 1903 and so addressed these problems without appealing to the theory of signs (as he then understood it). Determinations of meaning became power of signs -and everything that exists is a sign, not just possibly, but actually. Obviously this move committed Peirce to the idea that everything that exists is meaningful. Its epistemic determination as a part of our knowledge has no influence on the meaningfulness of existing entities after 1903. Obviously Dewey, James, Royce, and Rorty would not allow meaning and knowledge to be separated this way, but Whitehead and Bergson (more explicitly sympathetic to panpsychism) would say, "yes, matter is effete mind," or something similar. In any case meaning is unaffected by our knowing it in the sense that it is not dependent on that kind of determination in order to be, meaningfully. This toying with the independence of meaning from knowing is not usually associated with pragmatism, but it has to be considered in looking at Peirce's mature pragmatism.

\section{Eco's Ideas about Signs and Meaning}

Those who know Eco's ideas about knowledge will already have anticipated my case in this section. Eco differed from Peirce on this point about (what I am calling) concrete and abstract determination of the sign only insofar as Eco was unwilling to claim that signs are capable of dealing with subjective functions (recalling my sense of the term "function") regardless of whether these functions be abstract or concrete. In short, what is underdetermined is not the sign or the world, it is the subject's world. Thus, with this one exception, Eco agreed, I think, with the pre-1903 Peirce that signs, themselves, do form a bridge from the abstract realm to the concrete by means of something like a "signfunction." In Eco's case, however, this is not taken to provide for us any adequate account of the self and its functions, whether it is doubting or resolving that doubt tenaciously, scientifically, a prioristically, or from authority. For Eco, you can be subjectively wherever you happen to be and the knowledge relation may function as it objectively does regardless of whether you are the knower. What others know or no one knows functions the same in determining you as an object regardless of your subjective condition.

As an example, Eco's novel Foucault's Pendulum (which was his favorite of his own novels) has its significant action centered around a cryptic piece of paper left in a publishers office by a mysterious man (who may or may not have been murdered after his one visit to that office - we never find out). The piece of paper contains what seem to be notations about a location and what was to be found there. The three main characters come to 
believe that these "instructions" were written long ago by some people who had hidden the esoteric documents of a secret society (which secret society is an open question). At a crucial moment in the story, the girlfriend of the main character snatches the piece of paper (to see what all the fuss is about) and she rather convincingly shows that all the signs fit together around the hypothesis that it is in fact just a grocery list. But it doesn't matter. The action barrels on to the spectacular death of one of the main characters in spite of the revelation that the "secret" is no secret, just a grocery list. The main character, Casubon, becomes diffident, subjectively, about the meaning of the scrap of paper, and it makes no difference to the chain of objective determinations affecting him and his friend. Sign determinations and meanings function like this for Eco.

Being a pragmatist, I asked Eco once: “Was it just a grocery list?" His answer was "I don't know." Of course, the list was his own creation, as an author. I was asking whether in creating the list he had purposely adjusted it for both groceries and directions. He knew what I was asking. I believe he could have gone further and said "I can't know." How can Eco's semiotic theory deal with (1) "I don't know" as a sincere answer to my query about his intentions? and (2) why do I think he can go further and say: "I can't know" as an authorial response to the same? Most importantly, (3) how would a pragmatic theory of knowledge that has made Peirce's move after 1903 satisfy the constitutive question (and also, therefore the epistemological question) when the answer is either "I don't know" or "I can't know"?

I do not think that a conventional pragmatist (James, Dewey, Rorty) has anything interesting to say about this question because they refuse to radicalize the independence of meaning. Yet, I would insist, with Peirce, that the radical independence of meaning from situated acts of knowing is a genuine implication of any thorough-going pragmatism. Much to my disappointment, Royce also does not have anything interesting to say about this question. Only Peirce and Whitehead clearly recognized that meaning is a characteristic of possibility, not of actuality, and that every attempt to limit meaning to the actual undermines the future of knowledge.

It seems to me, as a pragmatist, that there is a fact of the matter, within the story, as to whether the cryptic piece of paper is or isn't a grocery list. To give up on that claim is to abandon the presupposed history (the unity of action, in Aristotle's terms) that governs the narrative. Foucault's Pendulum is not science fiction or fantasy or magical realism, or any other genre that tampers with the three unities. The novel studiously observes all three unities. Hence, the piece of paper has a history that either does or does not include having been a grocery list. Either these characters have a true belief or a false belief, regardless of whether any of them is experiencing any doubt. The fact (in the story) is that the piece of paper functions entirely as such a valuable document, even if everyone (except the girlfriend) is wrong about it. Eco could have left that scene out and it wouldn't have changed anything (except our level of understanding about the contingency of the interpretation of Casubon and his friends). Indeed, Eco need never have had the idea that it was a grocery list, and it still might have been one. But it seems very likely, to suspicious pragmatists, that the list started as a grocery list, and Eco knew it, and that is why he told us what the girlfriend saw. Yet, in this example, authorial intentions neither do determine the meaning here, nor can they. I think that accounts for Eco's answer, which he delivered playfully. He had been asked that question many times before, I would wager. I didn't get anything new from him. 

theories about language and intention. His answer to me about that question was that he didn't set out to do any such thing, but yes, he can see why people see that tendency in the novels. Without dropping back into a subjective "intentionalist" stance about the text, he allows that common sense will inform us that the theories are his and the novels are his and we ought not be surprised if they bear certain similarities. This does not satisfy a suspicious pragmatist. If the pragmatist is a Deweyan or Jamesian or Rortyan, no satisfaction will ever be had from Eco because they will not accept his solution (see below).

But what if the suspicious pragmatist is a Peircean? For Peirce, Eco's answer raises a further question, one which poses a difficulty for Eco, in my opinion. Indeed, Eco poses the problem himself in his discussion of types of forgeries, replicas, and fakes. This essay offers the situation in Foucault's Pendulum, but made even worse. Having disconnected meaning and knowledge, as Peirce finally did (embracing "unlimited semiosis" in Eco's terms, or a "truly general theory of signs" in my terms $\left.{ }^{12}\right)$, and seeing that fakes may never be identified as fakes, even though they are fakes (i.e., there is a fact of the matter), Eco asks "is a fake a sign?" (Eco 1990b: 184). He discusses "expressions" as incomplete signs, falling short of full-signhood for lack of Thirdness, but then Eco sets out the standard procedure for determining authenticity. Here, for our highest standards of knowing an original, an authentic original must be "a sign of its own origin" (Eco's emphasis). Recognizing the clear circularity, for us, of this habit of "modern philology," Eco says:

If a fake is not a sign, for modern philology the original, in order to be compared with its fake copy, must be approached as a sign. False identification is a semiosic web of misunderstandings and deliberate lies, whereas any effort to "correct" authentication is a clear case of semiosic interpretation or of abduction. (Eco 1990b: 193; Eco's emphasis)

Thus, we see that the detaching of meaning from knowledge has also sacrificed selfcorrection in the semiotic process. The effect is to make abduction the ground of all interpretation, and the result is that all knowledge is, for us, guesswork. Now, for Peirce such a result would be disastrous for his pragmatism. For Eco it seems to be only a strange feature of the world. He is light-hearted about it. Oh well, so knowledge is one kind of meaning, and not an especially reliable one. But, having destroyed all possibility of satisfactory criteria for knowing whether a given artifact is a fake, Eco says that "even though no single criterion [nor combination of criteria] is one-hundred-percent satisfactory, we usually rely on reasonable conjectures on the grounds of some balanced evaluation of the various tests. Thus we cast in doubt the socially accepted authenticity of an object only when some contrary evidence comes to trouble our established beliefs." (Eco 1990b: 200).

That sounds like Jamesian pragmatism, and like James's (mis)understanding of how doubt operates (what Peirce objected to). But James would never detach meaning from truth in such a fashion, regardless of what Bertrand Russell may have charged him with doing. James was a nominalist, not a nihilist. Further, we must remember that Eco has a highly nuanced account of abduction, and he allows (with Peirce) that abduction pervades all inference (hence all knowledge), but not all semiosis. Meaning can occur (if that is the right word) without anyone knowing it, ever. Now, Peirce maintains both the self-correcting character of scientific knowing and the independence of meaning in his mature pragmatism, but he is chastened. The distinction between reasoning about meaning and 
reasoning about knowledge is sharply distinguished in a manuscript intended for Peirce's Illustrations of the Logic of Science, as he tried for a final time (1909) to bring it into acceptable condition for publication. He thinks that when we reason about our states of consciousness, as a theory of knowledge requires, the subjective side of the task is almost impossible:

The observation of what one is doing and suffering [such as doubt] in his inner consciousness - assuming that it can be done at all, which some shrewdly doubt - is certainly far more difficult than is, for example, the management of a high-power microscope so as to resolve the most difficult test-objects; and to do simultaneously the two things that it is requisite to do at the same time in order - while concentrating all one's being upon a Reasoning, as one needs to do in order to discover new hypotheses at the same time - directly to observe what immediate consciousness (i.e., oneself, or that part of oneself that appears) does and suffers during that reasoning, is harder yet, by far. (Peirce 2014: 240-1) ${ }^{13}$

Thus, we see that the ubiquity of abduction wars with our efforts to catch a glimpse of ourselves as we move from doubt to resolution. We see Peirce moving away, as Eco did, from the subjective functioning of signs. This is not an adequation of the knowing subject to the reality known, and it is not simply the relief of inner doubts. These words were meant to be published alongside "The Fixation of Belief," and the other essays that had been basic to his theory of knowledge. But the construct of the "ideally situated inquirer in the infinitely distant future" is maintained by Peirce at this late date, so that "unlimited semiosis" (as Eco calls it) can be a presupposition of his philosophy without abdicating knowledge. In a letter to Paul Carus in 1909, Peirce apologizes for not being able to bring his theory of knowledge into acceptable condition, but attacks the problem of possibility again, saying that knowledge consists of acceptability (in the interim) of a proposition, but that these propositions mix actuality and possibility. His new theory (plausibility, verisimilitude, and probability) is a mess, in my opinion (and in his own), but he comes out saying:

As for the validity of the hypothesis, the retroduction [i.e., abduction], there seems at first to be no room at all for the question of what supports it, since from actual fact it only infers what may be, - may be and may be not. But there is a decided leaning to the affirmative side and the frequency with which that turns out to be an actual fact is to me quite the most surprising of all the wonders of the universe. I hope there are few men who are so often deceived as I. They surely cannot be many. Yet I could tell you of conjectures pronounced by me with a confidence I could not comprehend, and that were verified amazingly. I simply should not dare to tell them; I feel my credit would not support such tales. (Peirce 2014: 282)

Peirce goes on to list a number of cases in the history of science in which Faraday, Galilleo, and Kepler guessed what was true. Thus, where self-correction has fallen into disuse, the unreasonable success of science, in finding the right hypothesis, stands at the heart of knowing in the past and in the future. Pragmatism becomes, therefore, an leaning toward the affirmative that says, "go ahead, make something up, and then let it surprise you." I do not have to tell these readers that Eco wrote both novels and philosophy by making things up and then finding out they were true. Insofar as he gave in to the affirmative leaning, he was surely the sort of pragmatist Peirce was. I doubt that Eco read this letter to Carus, or the manuscript I cited above. But it isn't necessary to say he did. He really did follow Peirce in the affirmative leaning.

Eco realized he had to have a function that answered to Peirce's ideally situated inquirer - or there would be no difference between him and Rorty (and every nominalist aesthete). Eco wanted a more robust pragmatism than James, Rorty, even Dewey (Eco liked Dewey's 
aesthetics quite a lot). Eco's pragmatism was a pragmatism of independent meaning and ubiquitous abduction. He wanted a truly general semiotics. In discussing Peirce's theory of meaning, he said:

In the framework of Peirce's philosophy of unlimited semiosis, (i) every expression must be interpreted by another expression, and so on ad infinitum; (ii) the very activity of interpretation is the only way to define the contents of the expressions; (iii) in the course of the semiosic process the socially recognized meaning of expressions grows through the interpretations they undergo in different contexts and in different historical circumstances; (iv) the complete meaning of a sign cannot but be the historical recording of the pragmatic labor that has accompanied every contextual instance of it; (v) to interpret a sign means to foresee - ideally - all the possible contexts in which it can be inserted. Peirce's logic of relatives transforms the semantic representation of a term into a potential text. [...] In Eco 1976 (2.11.5) and 1984 (2.3) I have proposed a semantic model for the representation of the ideal content of indices (be they words, gestures or images) in an ideal situation of actual reference. (Eco 1990c: 213-4)

Obviously, for my purposes, we will see Eco's idea of growth as a substitute for self correction, his use of history and the "socially recognized meaning" as a substitute for the society of inquirers, the complete meaning of the sign foreseen operating as "the infinitely distant future" and the ideal content of indices as a substitute for ideally situated inquiry.

21 I do not mean to imply that Eco's theory of meaning is exactly the same as Peirce's. Elsewhere I have given a detailed discussion of the differences and similarities. Peirce and Eco approach this abstract/concrete duality of signs, and the theory of signs more generally, in quite different ways. The most obvious difference is that while Peirce's theory is triadic (revolving around sign, object and interpretant, with this latter bringing the sign-user into the formula), Eco's is a modification of the dyadic theory of Saussure (which is built up entirely from the relation of sign and signified - no sign-user is considered ${ }^{14}$ ), but Eco's dyad is operational, in my sense, and it is a difference that reaches to the core. For Eco, the fact of lying is more important than telling the truth, or attempting to tell the truth. As he says, "semiotics is in principle the discipline of studying everything which can be used in order to lie. If something cannot be used to tell a lie, conversely it cannot be used to tell the truth: it cannot in fact be used 'to tell' at all. I think that the definition of a 'theory of the lie' should be taken as a pretty comprehensive program for general semiotics." (Eco 1975: 6-7; 0.1.3).

Part of the reason I began this paper by using the awkward phrase a "truly general" theory of signs is to distinguish it from "a pretty comprehensive program for a general semiotics." At the level of function, i.e., sign-function, both Peirce and Eco sought to make out a truly general theory of signs. Although I believe the preceding discussion has made out in a general way the relation between Peirce and Eco, and I believe I have done so in a way that is suggestive of Eco's pragmatism, it is still only a preliminary outline.

\section{Triadic and Dyadic Semiotics}

I take Peirce and Eco to be the finest examples of their respective camps, and I really do think, although I do not wish to over-emphasize it, that their temperaments (to use James's characterization) are fairly close to being opposites. Both are playful, but Peirce's earnestness is very American. It is hard to sell such a viewpoint in the Old World. Still, I 
am confident that the limitations of these two theories accurately demonstrate and reflect the limits of semiotics more generally. Rather than trying to resolve the difficulties both Peirce and Eco have come up against, I propose that the theory of signs simply be restricted in such a way as to mollify the problem. I am eliminating the demand to resolve it. A pragmatic thesis guides the path forward: the theory of signs is capable of sufficiently accounting for the proper uses of language considered as a purely abstract (in the sense I have used that term above) phenomenon (i.e., appearance), but our difficulties begin when semiotics endeavors to consider any genetic or concrete (and therefore temporal) aspect of language. In short, semiosis happens at the level of possibility, not actuality. Meaning is the creature of possible relations and refuses to bow to actuality. That is why lies can go on forever and a truly general theory of signs loses its grip on knowledge, but pervades abduction. Thus, the limitation I propose for the theory of signs is that it should be restricted to being the theory of language considered abstractly. It should deal only with the way in which abstract signs are related to one another, and to their objects - that is, "objects" taken in the abstract sense, as a word among words; not in the sense of concrete, discretely existing individuals. As Eco's example goes, we do not worry about actual peanuts and their relation to peanut butter when we study semiotics. We worry only about what can be used to lie, and thus to tell the truth. ${ }^{15}$ This latter distinction between the concrete and abstract senses of the word "object" is of crucial significance for my thesis about the path forward, and it very much follows the discussions of "Objekt" versus "Gegenstand" one finds in Kant's three critiques. However, a detailed discussion of this matter awaits a later essay. ${ }^{16}$

\section{BIBLIOGRAPHY}

AUXIER Randall E., (2006), "Introduction," The Pragmatic Idealisms of Josiah Royce and John E. Boodin, as volume three of The Cambridge School of Pragmatism, John R. Shook \& André De Tien (eds), 4 vols, London, Thoemmes-Continuum Books, ix-xxi.

AUXIER Randall E., (2009), “Due tipi di pragmatismo," Discipline Filosofiche, special issue on “Epistemologie pragmatiste," Roberto Brigati \& Roberto Frega (eds), XIX (2), 27-43.

AUXIER Randall E., (2011), “Two Types of Pragmatism,” in Roberto Frega (ed.), Pragmatist Epistemologies, Lanham, Lexington Books, 187-205.

AUXIER Randall E., (2013), Time, Will, and Purpose: Living Ideas from the Philosophy of Joshia Royce, Chicago, Open Court.

AUXIER Randall E. \& Gary L. HERSTEIN, (2017), The Quantum of Explanation: Whitehead's Radical Empiricism, New York-London, Routledge.

DELEDAlLE Gérard, (1990), Charles S. Peirce: An Intellectual Biography, trans. Susan Petrilli, Philadelphia, John Benjamis.

ECo Umberto, (1975), A Theory of Semiotics, Bloomington, Indiana University Press. 
ECO Umberto, (1983), "Horns, Hooves, and Insteps: Some Hypotheses on Three Types of Abduction," in Umberto Eco \& Thomas A. Sebeok (eds), The Sign of Three: Dupin, Holmes, Peirce, Bloomington, Indiana University Press, 198-220.

ECO Umberto, (1988), Il pendolo di Foucault, Milan, Bompiani.

ECO Umberto, (1990a), “Abduction in Uqbar,” in Id., The Limits of Interpretation, Bloomington, Indiana University Press, 152-62.

ECO Umberto, (1990b), "Fakes and Forgeries," in Id., The Limits of Interpretation, Bloomington, Indiana University Press, 174-202.

ECO Umberto, (1990c), "Semantics, Pragmatics, and Text Semiotics," in Id., The Limits of Interpretation, Bloomington, Indiana University Press, 203-21.

ECO Umberto, (2010), Il cimitero di Praga, Milan, Bompiani.

FISCH Max H., (1978), "Peirce's General Theory of Signs," in Thomas A. Sebeok (ed.), Sight, Sound and Sense, Bloomington, Indiana University Press, 31-71.

FISCH Max H., (1986) Peirce, Semeiotic and Pragmatism, Kenneth L. Ketner \& Christian J. W. Kloesel (eds), Blomington, Indiana University Press, 321-55.

LANE Robert, (2007), “Peirce's Modal Shift: From Set Theory to Pragmaticism,” Journal of the History of Philosophy, 45 (4), 551-76.

OPPENHEIM Frank M., (2005), Reverence for the Relations of Life: Re-imagining Pragmatism via Josiah Royce's Interactions with Peirce, James, and Dewey, Notre Dame, University of Notre Dame Press, 7-60. PEIRCE Charles Sanders, (1931-1958), The Collected Papers of Charles Sanders Peirce, 8 vols, eds Charles Hartshorne, et al., Cambridge, Harvard Belknap Press.

PEIRCE Charles Sanders, (1984), Writings of Charles Sanders Peirce. A Chronological Edition, Volume II, 1867-1871, ed. Edward C. Moore, Bloomington, Indiana University Press.

PEIRCE Charles Sanders, (1986), Writings of Charles Sanders Peirce. A Chronological Edition, Volume III, 1872-1878, ed. Christian J. W. Kloesel, Bloomington, Indiana University Press.

PEIRCE Charles Sanders, (2014), Illustrations of the Logic of Science, Cornelis de Waal (ed.), Chicago, Open Court.

ROYCE Josiah, (1899), The World and the Individual: Series One, New York, MacMillan.

SHORT Thomas L., (2007), Peirce's Theory of Signs, Cambridge, Cambridge University Press.

ZEMAN Jay J., (1982), "Peirce on Abstraction,” The Monist, 65 (2), 211-29.

\section{NOTES}

1. [Note of the editor (the editor thanks Francesco Bellucci for his help). Peirce's semiotic theory after 1903 can be found in the Logic Notebook (1905-1906; 1909), in the letters to Welby (1904; 1908) and in the pragmatist papers (1905-1907). Auxier quotes (from De Waal's edition) a 1909 text that, according to Peirce, had to serve as an introduction to the re-publishing of the "Illustrations" of 1877-1878. Many different versions of this introduction are called "Meaning" (for instance, MS 637, 630, 640, 652 etc.). The reference here is to the Harvard Lectures of 1903, when Peirce returns to pragmatism after the works of 1877-1878. See also The Monist's pragmatist series (1905-1906).] 
2. I have examined the question about Royce in detail elsewhere (see Auxier 2013, ch. 4). I have also done a generalized comparison of types of pragmatism in Auxier (2011; 2009). See also Auxier 2006.

3. I am employing the terms "concrete" and "abstract" in a fashion similar to Whitehead's usage. I do this to avoid the word "mind," since the term (as Peirce used it) will be too easily confused with subjectivity of a Cartesian sort. The question of "mind" in analyzing Peirce and Eco is an important one, but that is not my topic in this essay, so I set it aside by focusing on what is "concrete" and "functional" as contrasted with what is "abstract" and "operative." For more on the role of abstraction in Whitehead's sense, see Auxier \& Herstein 2017. Peirce's manner of defining abstraction in his "New List of Categories" (1867) is in keeping with my usage here, but I intend the term more broadly, inclusive of Peirce's definition there. [Note of the editor. On Peirce's idea of "abstraction," see Zeman 1982.]

4. [Note of the editor. In his book Peirce's Theory of Signs (Short 2007), T. L. Short claims that, according to the young Peirce of the anti-cartesian essays, a sign refers to its object only through the mediation of another sign (semiotic idealism). On the contrary, according to the late Peirce (in Short's opinion, after 1885), a sign can refer to its object without mediation, as index is supposed to do. On the contrary, Auxier introduces here a different thesis: "As he matured, the concrete-functional aspect of the sign gradually diminished in his thinking about signs." (p. 3). "After 1903 (perhaps due to the influence of Royce), Peirce shifted his interpretation of his categories and solved this problem by treating signs as determined only abstractly." (p. 6). And a very different thesis concerns also the idea of "infinite semiosis": "Having disconnected meaning and knowledge, as Peirce finally did (embracing 'unlimited semiosis' in Eco's terms, or a 'truly general theory of signs' in my terms)." (p. 10). According to Short, it was the young Peirce to believe in unlimited semiosis, while, around 1907, Peirce would have put a limit to it through the idea of habit. Auxier challenges this idea here.]

5. Eco's parsing of abduction (which dominates all knowing, for Peirce, as he reports) into creative abductions, meta-abductions, and over/undercoded abductions is actually one version of stating this problem. Other commentators have stated the struggle otherwise, but everyone agrees that Peirce himself was unsatisfied with his solution. I will present this problem in my own terms, but I think Eco's essay shows he was keenly aware of the sort of problem I am describing. See Eco 1983. Eco repeats this favorite criticism of Peirce in Eco 1990a. It lies beyond the scope of this paper to make an argument for Peirce's development. Generally I follow the course described by Deledalle 1990. Deledalle achieves an admirable perspicacity in this book by leaving aside complications about external influences on Peirce's thinking, simply following the trail of development in Peirce's writings and manuscripts.

6. For the history of their relationship, see Oppenheim 2005. As good as this treatment is, Oppenheim has overlooked some very important evidence and the implications.

7. See Peirce, The Collected Papers of Charles Sanders Peirce, 8 vols. eds C. Hartshorne et al. (Cambridge, Harvard Belknap Press, 1931-1958), vol 8, p. 75 ff. (paragraphs 101-104; hereafter this collection will be cited as "CP" followed by the vol. and paragraph number, e.g., CP 8:101, and so forth). Here Peirce contrasts Royce's view of possibility with his own (paragraph 102).

8. [Note of the editor. On the notion of "possibility" after 1903, see Lane 2007, who outlines an evolution of this concept after 1896.]

9. See "The Fixation of Belief," 1877, W 3: 242-57; CP 5.358-87.

10. I hope that readers will remember Eco's entertaining use of the arguments about ruminants in his essay on Peirce, "Horns, Hooves, and Insteps: Some Hypotheses about Three Types of Abduction" (Eco 1983).

11. See "On a New List of Categories," W 2:49-59; CP 1.545-59. 
12. [Note of the editor. On the "truly general theory of signs," a classic references is M. H. Fisch, "Peirce's General Theory of Signs" (Fisch 1978; 1986).]

13. De Waal has done the scholarly community a tremendous service by compiling what this book would have looked like if Peirce had been able to finish it. His careful documentation of the full path from the 1877 manuscripts through to the last versions of the book are, in my opinion, the single most telling document published to date that demonstrates the development of Peirce's thought. My statements in this paper about Peirce's development are, I believe, in close keeping with what this book shows.

14. Eco very adeptly compares Saussure and Peirce right at the beginning of his own theory, and neatly praises Peirce while reducing him to Saussure in order to avoid dealing with subjectivity (See Eco 1975: 16-7; 0.5).

15. Ibid.

16. Unhappily, one needs also a temporal theory of language to supplement this version of semiotics, and I will not be able to address that here. I have written elsewhere about it.

\section{ABSTRACTS}

This paper aims to consider Peirce and Eco's approach to signs and semiotics in order to assess their relation to Peirce's mature pragmatism. Both thinkers attempted to set out a truly general theory of signs, and ran into difficulties on similar points. I show that the responses of Peirce and Eco to the difficulties that arose in seeking a truly general theory of signs were quite different. And yet, the differences are not so deep as to prevent us from thinking of both Peirce and Eco as pragmatists, and perhaps of a similar stripe.

\section{AUTHOR}

RANDALL E. AUXIER

Southern Illinois University Carbondale personalist61[at]gmail.com 